\title{
Implementasi Pendidikan Karakter Melalui Budaya Religius dalam Mengembangkan Soft Skill Siswa di SD Ar Rahman Kertosono
}

\author{
Muhamad Umar Fauzi dan Maulidatul Khoiriyah \\ Sekolah Tinggi Agama Islam Miftahul ‘Ula Nglawak Kertosono Nganjuk \\ Email: fauziu047@gmail.com
}

\begin{abstract}
Abstrak: "Upaya pembentukan karakter yang sesuai dengan budaya bangsa ini tidak semata-mata hanya dilakukan melalui serangkaian kegiatan belajar mengajar di sekolah, akan tetapi juga melalui pembiasaan (habituasi) dalam kehidupan. Seperti religius, jujur, disiplin, tanggung jawab dan lain sebagainya. Dalam mewujudkan pendidikan yang sesuai dengan cita-cita bangsa, implementasi pendidikan karakter di sekolah sangatlah diperlukan karena sekolah merupakan wadah dalam membentuk karakter siswa. Pembentukan karakter siswa dapat dilakukan salah satunya melalui pendekatan budaya religius. Dimana agama mengandung ajaran tentang berbagai nilai luhur dan mulia bagi manusia. Agama juga mempunyai keterkaiatan yang sangat erat dengan pendidikan karakter. Implementasi pendidikan karakter di SD Ar Rahman Kertosono adalah melalui budaya religius yang sesuai dengan nilai-nilai pendidikan karakter dan visi misi SD Ar Rahman. Selain itu SD Ar Rahman juga memiliki program khas dan rapot khusus yang memuat penilaian kegiatan non akademik siswa. Dalam pelaksanaan penerapan pendidikan karakter siswa senantiasa dipantau dan diawasi oleh guru dan orang tua melalui buku performansi atau buku penghubung. Ada beberapa faktor pendukung dan faktor penghambat implementasi pendidikan karakter melalui budaya religius dalam mengembangkan soft skill siswa diantaranya dari pihak sekolah, orang tua, siswa dan faktor dari luar. Penerapan pendidikan karakter di SD Ar Rahman Kertosono memiliki dampak yang sangat signifikan bagi siswa karena tanpa disadari siswa akan terbiasa melakukan hal-hal positif dan menerapkannya dalam kehidupan sehari-hari baik dalam kehidupan dirumah, sekolah maupun masyarakat luas."
\end{abstract}

Kata Kunci: Pendidikan Karakter, Budaya Religius, Soft Skill

\section{Pendahuluan}

Kemajuan suatu bangsa sangat bergantung pada kualitas sumber daya manusia. Sumber daya manusia yang berkualitas akan berpengaruh pada kualitas taraf hidup suatu bangsa. Pendidikan menjadi hal yang sangat berperan dalam meningkatkan kualitas sumber daya manusia. Menurut undang-undang nomor 20 tahun 2003 tentang Sistem Pendidikan Nasional pasal 3 yang menegaskan bahwa pendidikan nasional berfungsi mengembangkan kemampuan dan membentuk watak serta peradaban bangsa yang bermartabat dalam rangka mencerdaskan kehidupan bangsa, bertujuan untuk mengembangkan potensi peserta didik agar menjadi manusia yang beriman dan bertakwa kepada Tuhan Yang Maha Esa, berakhlak mulia, sehat, 
berilmu, cakap, kreatif, mandiri dan menjadi warga negara demokratis serta bertanggung jawab. ${ }^{1}$ Berdasarkan UU tersebut jelas terlihat bahwa tujuan pendidikan nasional tidak untuk mencerdaskan anak secara intelektual, tetapi juga mengembangkan kepribadian mereka secara utuh. Tantangan kehidupan global sekarang ini justru membutuhkan anak-anak, generasi muda dan manusia yang memiliki kepribadian, kemandirian, kreativitas dan semangat untuk melakukan adaptasi dan perubahan kehidupan, bukan sekedar generasi muda yang menguasai pengetahuan teknis, tetapi lemah kepribadiannya. ${ }^{2}$

Pendidikan dapat dimaknai sebagai usaha untuk membantu peserta didik mengembangkan potensinya (hati, pikir, rasa dan karsa serta raga) untuk mengahadapi masa depan. $^{3}$ Pendidikan menurut Ki Hajar Dewantara adalah upaya untuk memajukan perkembangan budi pekerti (kekuatan batin), pikiran (intelektual) dan jasmani anak-anak. Dalam pengertian tersebut, pendidikan tidak hanya untuk intelektualitas saja tetapi juga untuk membimbing karakternya (budi pekerti). ${ }^{4}$

Berdasarkan UU tersebut jelas terlihat bahwa tujuan pendidikan nasional tidak hanya untuk mencerdaskan anak secara intelektual saja, tetapi juga mengembangkan kepribadian mereka secara utuh. Tantangan kehidupan global sekarang ini justru membutuhkan anak-anak, generasi muda dan manusia yang memiliki kepribadian, kemandirian, kreativitas dan semangat untuk melakukan adaptasi dan perubahan kehidupan, bukan sekedar generasi muda yang menguasai pengetahuan teknis, tetapi lemah kepribadiannya. ${ }^{5}$

Di negara kita, pendidikan diharapkan dapat bersifat humanisreligius, dimana dalam pengembangan kehidupan (ilmu pengetahuan) tidak terlepas dari nilai-nilai keagamaan dan kebudayaan. Masyarakat di negara ini menghargai nilai-nilai keagamaan dan kebudayaan sebagai sumber membangun kehidupan yang harmonis diantara bermacam-macam etnik, kelompok, sosial dan daerah. Lebih lanjut dikatakan bahwa nilai keagamaan bukan dipandang sebagai nilai ritual yang sekedar digunakan untuk menjalankan upacara keagamaan dan tradisi, tetapi diharapkan menjadi bagian yang tidak terpisahkan dari kegiatan kehidupan untuk memenuhi kebutuhan kesejahteraan material, sosial, harga diri, intelektual dan aktualisasi diri. ${ }^{3}$

1 Undang-Undang Republik Indonesia Nomor 20 Tahun 2003 Tentang Sistem Pendidikan Nasional. (Jakarta:Transmedia Pustaka, 2007), 5.

2 Dyah Kumalasari, Agama Dan Budaya Sebagai Basis Pendidikan Karakter di Sekolah. (Yogyakarta: Suluh Media, 2018), 13. ${ }^{3}$ Ibid, 57.

${ }^{3}$ Muclas Samani, Hariyanto, Pendidikan Karakter. (Bandung: PT Remaja Rosdakarya, 2013), 37.

${ }^{4}$ Dyah Kumalasari, Agama Dan Budaya Sebagai Basis Pendidikan Karakter Di Sekolah. (Yogyakarta: Suluh Media, 2018), 29.

5 Dyah Kumalasari, Agama Dan Budaya Sebagai Basis Pendidikan Karakter di Sekolah. (Yogyakarta: Suluh Media, 2018), 13. ${ }^{3}$ Ibid, 57. 
Dalam mewujudkan cita-cita tersebut, sekolah memiliki peranan penting dalam pencapaiannya. Salah satu usaha yang dilakukan oleh sekolah guna mengembangkan pendidikan di Indonesia yakni dengan menerapkan pendidikan karakter. Pendidikan karakter merupakan pendidikan yang mengembangkan karakter yang mulia (good character) dari peserta didik dengan mempraktikkan dan mengajarkan nilai-nilai moral dan pengambilan keputusan yang beradab dalam hubungan sesama manusia maupun dalam hubungan dengan TuhanNya. ${ }^{6}$

\section{Pendidikan Karakter di SD Ar-Rahman Kertosono}

SD Ar Rahman merupakan sekolah yang berada di bawah naungan Lembaga Pendidikan Islam dan Sosial Ar Rahman. SD Ar Rahman tampak memiliki komitmen yang tinggi dalam menanamkan dan menerapkan pendidikan karakter melalui budaya religius dalam mengembangkan soft skill siswa. Hal ini dapat dilihat dari diterapkannya pendidikan karakter melalui nilai-nilai Islami. Dalam konteks pendidikan di sekolah, salah satu karakteristik pendidikan yang mendasar adalah nilai-nilai religius. Hal tersebut terlihat dari visi dan misi SD Ar Rahman yaitu menjadi lembaga berprestasi yang Islam didukung dengan SDM handal, inovatif, fasilitas memadai dalam lingkungan kondusif dan mempersiapkan peserta didik menjadi pribadi yang berakidah mantab, berkemampuan akademis tinggi dan berkarakter serta berguna bagi umat, bangsa atau negara sesuai dengan perkembangannya. ${ }^{7}$

Pendidikan karakter adalah proses pemberian tuntunan kepada peserta didik untuk menjadi manusia seutuhnya yang berkarakter dalam dimensi hati, pikir, raga, serta rasa dan karsa. Pendidikan karakter dapat dimaknai sebagai pendidikan nilai, pendidikan budi pekerti, pendidikan moral, pendidikan watak, yang bertujuan mengembangkan kemampuan peserta didik untuk memberikan keputusan baik-buruk, memelihara apa yang baik, dan mewujudkan kebaikan itu dalam kehidupan sehari-hari dengan sepenuh hati. ${ }^{8}$

Pendidikan karakter bertujuan untuk meningkatkan mutu proses dan hasil pendidikan yang mengarah pada pembentukan karakter dan akhlak mulia peserta didik secara utuh, terpadu dan seimbang, sesuai dengan standar kompetensi lulusan pada setiap satuan pendidikan. Melalui pendidikan karakter peserta didik diharapkan mampu secara mandiri meningkatkan dan menggunakan pengetahuannya, mengkaji dan menginternalisasikan serta

\footnotetext{
${ }^{6}$ Rosdiatun, Model Implementasi Pendidikan Karakter. (Gresik: Caremedia Communication, 2018), 21.

${ }^{7}$ Dokumentasi SD Ar Rahman

${ }^{8}$ Muclas Samani, Hariyanto, Pendidikan Karakter. (Bandung: PT Remaja Rosdakarya, 2013), 43.
} 
mempersonalisasikan nilai-nilai karakter dan akhlak mulia sehingga terwujud dalam perilaku sehari-hari. Pendidikan karakter pada intinya bertujuan membentuk bangsa yang tangguh, kompetitif, berakhlak mulia, bermoral, bertoleran, bergotong royong, berjiwa patriotik, berkembang dinamis, berorientasi ilmu pengetahuan dan tegnologi yang semuanya dijiwai oleh iman dan takwa kepada Tuhan Yang Maha Esa. ${ }^{9}$

Implementasi pendidikan karakter di SD Ar Rahman dibudayakan dengan cara menyisipkan dalam semua mata pelajaran sesuai dengan kurikulum 2013 yang menekankan pendidikan karakter pada siswa yang dalam pembelajarnnya tidak lagi berpusat pada guru melainkan berpusat pada siswa dan diimplementasikan dalam kehidupan sehari-hari baik di sekolah, rumah maupun lingkunganya. Dengan demikian implementasi pendidikan karakter dapat terintegrasikan dalam setiap kegiatan pembelajaran baik di kelas maupun di luar kelas. ${ }^{10}$ Karakter dapat dimaknai sebagai nilai dasar yang membangun kepribadian seseorang, terbentuk baik karena pengaruh hereditas maupun pengaruh lingkungan, yang membedakannya dengan orang lain, serta diwujudkan dalam sikap dan perilakunya dalam kehidupan sehari-hari. ${ }^{11}$

Dalam perencanaannya, pihak sekolah juga melakukan sosialisasi terlebih dahulu kepada seluruh elemen sekolah dan orang tua siswa. Sehingga implementasi pendidikan karakter melalui budaya religius dalam mengembangkan soft skill siswa dapat berjalan sesuai dengan tujuan sekolah. Implementasi pendidikan karakter melalui budaya religius di SD Ar Rahman dilatar belakangi oleh pesatnya perkembangan teknologi dan informasi yang apabila tidak diimbangi dengan pendidikan karakter maka akan menyebabkan ketimpangan karena pendidikan karakter itu sendiri merupakan pendidikan yang berkaitan dengan spiritual dan emosional seseorang.

Dalam menyelenggarakan pendidikan SD Ar Rahman tidak hanya mengutamakan ranah IQ atau pengetahuan saja, namun juga menumbuhkan kecerdasan spiritual, kecerdasan emosional dan kecerdasan sosial. Pada saat kenaikan kelas, penilaian tidak hanya dilihat dari aspek akademik saja tetapi nilai non akademik yaitu aspek akhlak juga menjadi pertimbangan sekolah. Dalam memantau kegiatan siswa saat berada di rumah maupun di sekolah, SD Ar Rahman menggunakan buku performansi siswa. Selain itu, buku performansi juga berfungsi sebagai alat penghubung antara orang tua dengan sekolah. SD Ar Rahman juga memiliki rapot

\footnotetext{
${ }^{9}$ Abdullah Hamid, Pendidikan Karakter Berbasis Pesantren. (Surabaya: Imtiyaz, 2017),

${ }^{10}$ Elisa Ina Kristanti, wawancara, Kertosono, 15 Juni 2019

${ }^{11}$ Muclas Samani, Hariyanto, Pendidikan Karakter. (Bandung: PT Remaja Rosdakarya, 2013), 43.
} 
khusus yang berisi penilaian kegiatan-kegiatan non akademik seperti penilaian kegiatan mukhafadzoh, keterampilan khusus, kegiatan sekolah dan aktivitas saat berada di sekolah.

Dalam menerapkan pendidikan karakter, SD Ar Rahman memiliki program pembelajaran khas yang meliputi tiga program yaitu program utama, program penunjang dan program unggulan. Program utama meliputi pembinaan mata pelajaran, pengembangan life skill berbasis pada EQ dan IQ serta pembinaan ekstrakurikuler. Program penunjang meliputi budaya jawa, bahasa Inggris, pembelajaran ibadah praktis, hafalan do'a sehari-hari, hafalan surat pendek dan kalimat tayyibah. Program unggulan SD Ar Rahman meliputi program pondok semalam (PONDAS), pondok ramadhan (PONDAN), program super tahfidz, mengaji Al-Qur'an metode Ummi, pengenalan profesi, outbond and outdoor education, pemeriksaan kesehatan tubuh dan gigi, pemantauan tumbuh kembang anak, pembinaan siswa berbakat, full day school, motivasi building dan pendidikan karakter. Program-program tersebut dilaksanakan dan dibudayakan oleh SD Ar Rahman dengan tujuan mengembangkan kemampuan SQ, IQ maupun EQ siswa.

Budaya manusia erat kaitannya dengan usaha sadar dari manusia dalam penyelenggaraan pendidikan yang bertujuan untuk meningkatkan kesejahteraannya. Tiga wujud budaya yaitu wujud ideal, wujud norma dan wujud material yang salah satu media pewarisannya adalah melalui pendidikan, baik di sekolah, dalam keluarga dan dalam masyarakat. Nilai budaya sifatnya abstrak, tidak tampak dan tidak dapat diraba. Tetapi nilai budaya menjadi acuan masyarakat atau kelompok masyarakat yang berhubungan dengan perilaku individu. Agar acuannya menjadi jelas, maka kelompok masyarakat menciptakan norma, baik tertulis maupun tidak tertulis, misalnya norma hukum, norma sopan santun, norma kesusilaan dan sebagainya. ${ }^{12}$

Berdasarkan hasil dokumentasi nilai-nilai religius yang diterapkan di SD Ar Rahman dibagi menjadi dua kategori yaitu sikap religius dan perilaku religius.

1. Sikap religius meliputi berpartisipasi dalam perayaan hari besar Islam yang meliputi perayaan isra' mi'raj, peringatan maulid nabi, pondok ramadhan, hari raya qurban, manasik haji dan peringatan tahun baru hijriyah.

2. Perilaku religius meliputi membaca asma'ul husna, sholat dhuha, dzikir pagi, muroja'ah juz 30, mengaji Al-Qur'an metode Ummi, terjemah Al-Qur'an metode tamyiz, berdo'a sebelum

\footnotetext{
${ }^{12}$ Dyah Kumalasari, Agama Dan Budaya Sebagai Basis Pendidikan Karakter Di Sekolah. (Yogyakarta: Suluh Media, 2018), 60-61.
} 
dan sesudah belajar, membaca do'a pada setiap akan melakukan pekerjaan, dan kegiatankegiatan religi lainnya yang dilakukan setiap hari. ${ }^{13}$

Setiap pagi para siswa melaksanakan sholat dhuha berjama'ah, muroja'ah juz 30, mengaji ummi dan dilanjut dengan proses pembelajaran. Pada pukul tujuh para siswa antri mengambil air wudhu dan melaksanakan sholat dhuha secara berjama'ah, kelas satu dan kelas dua melaksanakan sholat dhuha berjama'ah di mushola kecil. Sedangkan kelas tiga sampai kelas enam melaksanakan sholat dhuha di mushola besar dan dilanjut dengan muroja'ah juz 30 dan mengaji menggunakan metode ummi.

Dengan pembiasaan tersebut diharapkan mampu membangun rasa kemusiaan, tenggang rasa dan soft skill siswa. Pendidikan karakter pada intinya bertujuan membentuk bangsa yang tangguh, kompetitif, berakhlak mulia, bermoral, bertoleran, bergotong royong, berjiwa patriotik, berkembang dinamis, berorientasi ilmu pengetahuan dan teknologi yang semuanya dijiwai oleh iman dan takwa kepada Tuhan Yang Maha Esa. ${ }^{14}$ Dalam menerapkan pendidikan karakter, SD Ar Rahman memiliki kegiatan pengembangan melalui budaya religius yang meliputi kegiatan rutin, kegiatan spontan dan kegiatan teladan.

1. Kegiatan rutin adalah kegiatan yang dilakukan secara regular, baik di kelas maupun di sekolah. Bertujuan untuk membiasakan siswa mengerjakan sesuatu dengan baik. Jenis kegiatannya yaitu penjemputan di pintu gerbang sekolah, budaya 5S (senyum, sapa, salam, sopan dan santun), upacara setiap hari senin, pemeriksaan kebersihan dan kelengkapan, senam pagi pada hari sabtu, sholat dhuha, sholat dzuhur, sholat ashar dan mengaji Al-Qur'an dan muroja'ah juz 30.

2. Kegiatan spontan adalah kegiatan yang dapat dilakukan kapan saja, tanpa dibatasi oleh ruang. Bertujuan untuk memberikan pendidikan pada saat itu juga, terutama dalam disiplin dan sopan santun serta kebiasaan yang baik. Jenis kegiatannya yaitu membiasakan memberi salam, membiasakan membuang sampah pada tempatnya, membiasakan antri pada waktu wudhu, membiasakan mengatasi silang pendapat (pertengkaran) dengan benar, membiasakan bersedekah dan jujur dalam setiap perkataan.

3. Kegiatan teladan adalah kegiatan yang dapat dilakukan kapan saja dan dimana saja yang lebih mengutamakan pemberian contoh dari guru dan pengelola pendidikan yang lain kepada siswanya. Bertujuan memberikan contoh tentang kebiasaan yang baik. Jenis kegiatannya yaitu budaya hidup bersih, memberi contoh berpakaian rapi, memberi contoh

\footnotetext{
${ }^{13}$ Dokumentasi SD Ar Rahman

${ }^{14}$ Abdullah Hamid, Pendidikan Karakter Berbasis Pesantren. (Surabaya: Imtiyaz, 2017), 12.
} 
memuji hasil kerja yang baik, memberi contoh datang tepat waktu dan memberi contoh hidup sederhana. ${ }^{15}$

Pencapaian dari hasil belajar sebagai hasil pengembangan intelektual atau kognitif siswa harus juga diimbangi dengan pencapaian dan perkembangan pada aspek soft skill siswa. Konsep soft skill maksudnya tidak lain adalah karakter atau sikap dan perilaku yang menjunjung tinggi nilai-nilai kemuliaan, seperti nilai kejujuran, kesabaran, keberanian, kemandirian, tanggung jawab, kepedulian dan sebagainya. ${ }^{16}$ SD Ar Rahman Kertosono memiliki kurikulum khas yang membedakannya dengan sekolah lain seperti kegiatan pondok anak semalam yang dilakukan setiap akhir semester, program super tahfiz, kegiatan munaqosah. Pada setiap kegiatan yang diselenggarakan sekolah terdapat koordinator yang ditunjuk oleh kepala sekolah guna untuk mengondisikan berjalannya suatu kegiatan. ${ }^{17}$ Implementasi pendidikan karakter melalui Budaya Religius dalam mengembangkan soft skill siswa di SD Ar Rahman adalah dengan menerapkan nilai-nilai pendidikan karakter yaitu:

1. Peduli sosial

Salah satu nilai pendidikan karakter melalui Budaya Religius dalam mengembangkan soft skill siswa yang diterapkan di SD Ar Rahman yaitu peduli sosial. Kegiatan yang mencerminkan nilai peduli sosial yaitu pada kegiatan pondok ramadhan (PONDAN) para siswa membagikan ta'jil dan zakat. Para siswa diberi kesempatan untuk membagikan ta'jil dan zakat dengan tujuan agar siswa dapat mengenal siapa saja yang berhak menerima pemberian tersebut. Pada setiap pekan budiman atau pekan budaya Ar Rahman yang diselenggarakan pada awal tahun pelajaran. SD Ar Rahman mengadakan kegiatan bakti sosial untuk membagikan sembako kepada fakir miskin maupun anak yatim piatu. Hal ini menunjukkan bahwa nilai peduli sosial telah diterapkan di SD Ar Rahman.

2. Cinta tanah air

Nilai cinta tanah air telah diterapkan di SD Ar Rahman seperti yang dikemukakan oleh Ibu Nur Atiningsih bahwa pada setiap hari senin seluruh warga sekolah melaksanakan upacara bendera dan di sepuluh menit terakhir pembelajaran seluruh kelas menyanyikan lagu wajib dan lagu daerah. Kegiatan ini bertujuan untuk menanamkan rasa cinta siswa kepada tanah air. Pendidikan karakter dimaknai sebagai suatu sistem penanaman nilai-nilai komponen pengetahuan, kesadaran atau kemauan dan tindakan untuk melaksanakan nilai-

\footnotetext{
${ }^{15}$ Dokumentasi SD Ar Rahman Kertosono

${ }^{16}$ Wani Tune Sumar, Intan Abdul Razak, Strategi Pembelajaran dalam Implementasi Kurikulum Berbasis Soft Skill. (Yogyakarta: Deeplubish, 2016), 157.

${ }^{17}$ Nur Atiningsih, wawancara, Kertosono, 28 Mei 2019
} 
nilai tersebut baik terhadap Tuhan Yang Maha Esa, diri sendiri, sesama, lingkungan maupun kebangsaan sehingga menjadi manusia yang insan kamil. Penanaman nilai pada warga sekolah maknanya bahwa pendidikan karakter baru akan efektif jika tidak hanya siswa, tetapi juga para guru, kepala sekolah dan tenaga non pendidik di sekolah semua harus terlibat dalam pendidikan karakter. ${ }^{18}$

Dari data dokumentasi SD Ar Rahman selalu menyelenggarakan perlombaan pada peringatan HUT RI. SD Ar Rahman juga senantiasa berpartisipasi aktif dalam mengikuti lomba PBB atau gerak jalan dan karnaval yang diselenggarakan setiap tahun oleh pemerintah Kecamatan Kertosono dalam memperingati HUT RI. Hal ini menunjukkan telah ditanamkan dan diterapkannya rasa cinta tanah air di SD Ar Rahman.

3. Disiplin

Disiplin merupakan tindakan yang menunjukkan perilaku tertib dan patuh pada berbagai peraturan dan ketentuan. Ibu Nur Atiningsih mengungkapkan bahwa sebelum awal tahun pelajaran, kepala sekolah beserta para guru mengadakan rapat untuk menentukan peraturan-peraturan yang ada di SD Ar Rahman beserta dengan sanksinya. Sanksi yang diberikan kepada pelanggar merupakan sanksi yang mengandung unsur pendidikan seperti membaca istighfar, membaca Al-Qur'an, menghafal surat-surat pilihan yang telah ditentukan. ${ }^{19}$ Hal ini menunjukkan bahwa nilai disiplin telah diterapkan di SD Ar Rahman.

4. Mandiri

Mandiri yaitu karakter yang dapat mendorong seseorang untuk melakukan berbagai kegiatan secara sendiri tanpa bergantung pada orang lain. Nilai mandiri ditanamkan kepada siswa melalui budaya religius diantaranya ialah siswa dibiasakan memakai sepatu, menyisir rambut, menata bekal, mencuci alat makan, mencuci pakaian secara mandiri oleh siswa. Kegiatan tersebut mendapat penilaian dan masuk dalam ujian praktek di SD Ar Rahman. Kegiatan Pondok anak semalam atau PONDAS juga merupakan salah satu upaya sekolah dalam menanamkan nilai mandiri kepada siswa. ${ }^{20}$ Pondok anak semalam dilaksankan setiap akhir semester mulai dari kelas satu sampai dengan kelas enam. Kegiatan PONDAS berlangsung hanya semalam untuk kelas satu sampai dengan kelas tiga. Namun untuk kelas empat sampai dengan enam kegiatan PONDAS berlangsng

\footnotetext{
${ }^{18}$ Muclas Samani, Hariyanto, Pendidikan Karakter. (Bandung: PT Remaja Rosdakarya, 2013), 46.

${ }^{19}$ Nur Atiningsih, wawancara, Kertosono, 28 Mei 2019

${ }^{20}$ Nur Atiningsih, wawancara, Kertosono, 28 Mei 2019
} 
selama empat hari tiga malam. ${ }^{21}$ Nabila siswa kelas III SD Ar Rahman mengungkapkan bahwa ia merasa senang dengan adanya kegiatan PONDAS karena dengan begitu ia merasa memiliki banyak teman dalam melakukan segala aktifitas, ia juga merasa senang dengan kegiatan-kegiatan yang dilakukakan saat PONDAS seperti mendengarkan cerita, bermain, mengaji, makan dan tidur bersama. ${ }^{22}$ Hal ini menunjukkan bahwa SD Ar Rahman sudah menanamkan dan menerapkan nilai mandiri kepada siswa.

5. Jujur

Contoh penerapan nilai kejujuran di SD Ar Rahman adalah tidak mengambil barang yang bukan miliknya, selalu memberikan pengumuman jika menemukan barang maupun uang. Ibu Siti Farida Ariani mengungkapkan bahwa siswa SD Ar Rahman jarang sekali berbohong. Jika menemukan uang ataupun barang pasti di kembalikan atau memberikan barang temuan kepada guru untuk diumumkan. ${ }^{23}$ Hal ini merupakan salah satu penanaman dan penerapan nilai kejujuran yang diterapkan pada diri siswa.

6. Kreatif

Berdasarkan hasil observasi pada tanggal 9 Mei 2019 peneliti mendengar dan melihat para siswa dan guru kelas II SD Ar Rahman bersama-sama menyanyikan yel-yel dan lagu islami. Di depan kelas terdapat beberapa seni kaligrafi, gambar, puisi dan cerita karya para siswa yang tertempel di mading. Di awal tahun pelajaran, siswa berlomba menciptakan yel-yel motivasi dan mars kelas. Setiap kelas juga memiliki nama kelas yang unik, dimana temanya selalu berbeda di setiap tahun seperti tema nama tokoh islam, tema sifat-sifat nabi dan lain sebagainya. ${ }^{24} \mathrm{Hal}$ ini menunjukkan telah diterapkannya nilai kreatif pada diri siswa SD Ar Rahman.

7. Sehat dan bersih

Pada hakikatnya soft skill merupakan istilah sosiologis yang berkaitan dengan seseorang “EQ” (Emotional Intelligence Quotient) kumpulan karakter kepribadian, rahmat sosial, komunikasi, bahasa, kebiasaan, pribadi, keramahan dan optimis yang menjadi cirri hubungan dengan orang lain. ${ }^{25}$ Sejak awal berdiri, SD Ar Rahman sudah menerapkan kehidupan yang sehat dan bersih. Berdasarkan observasi yang peneliti lakukan pada tanggal

\footnotetext{
${ }^{21}$ Mariatul Qibtiyah, wawancara, Kertosono, 28 Mei 2019

${ }^{22}$ Nabila, wawancara, Kertosono, 9 Mei 2019

${ }^{23}$ Siti Farida Ariani, wawancara, Kertosono, 28 Mei 2019

${ }^{24}$ Nur Atiningsih, wawancara, Kertosono, 28 Mei 2019

${ }^{25}$ Sutardi, Solusi Mahir Kimia. (Yogyakarta: Deepublish CV Budi Utama, 2012), 42.
} 
2 April 2019 di SD Ar Rahman. Lingkungan SD Ar Rahman Kertosono terlihat bersih dan rapi. Di setiap sudut ruangan maupun kelas sudah tersedia tempat pembuangan sampah.

SD Ar Rahman Kertosono memiliki program pemeriksaan kesehatan pada setiap semester yaitu pemeriksaan kesehatan umum dan pemeriksaan kesehatan gigi. Setiap tahun SD Ar Rahman juga mengadakan observasi psikologi untuk mengobservasi tingkat IQ dan EQ siswa. Pihak sekolah juga menyediakan tempat pembuangan sampah di setiap kelas dan sudut ruangan untuk menjaga kebersihan lingkungan. Hal ini menunjukkan telah diterapkannya rasa cinta pada diri sendiri dan lingkungan di SD Ar Rahman.

8. Tanggung jawab

Penerapan nilai tanggung jawab di SD Ar Rahman dimulai dari hal terkecil seperti melaksanakan tugas dengan baik, menjaga barang pribadi dan barang milik umum dengan baik, menjaga kebersihan lingkungan, melaksanakan piket sesuai dengan jadwal dan lain sebagainya. ${ }^{26}$ Hal ini menunjukkan telah diterapkannya nilai tanggung jawab di SD Ar Rahman.

9. $\quad$ Gotong royong

Pada draf grand design pendidikan karakter diungkapkan nilai-nilai yang terutama akan dikembangkan dalam budaya satuan pendidikan formal dan non formal yaitu jujur, tanggung jawab, cerdas, sehat dan bersih, peduli, kreatif dan gotong royong. ${ }^{27}$ Gotong royong merupakan suatu kegiatan yang dilakukan secara bersama-sama untuk mencapai tujuan bersama. Berdasarkan hasil observasi pada tanggal 9 Mei 2019 Peneliti melihat secara langsung para siswa melakukan gotong royong membersihkan kelas, membersihkan halaman dan membersihkan lapangan. ${ }^{28} \mathrm{Hal}$ ini menunjukkan bahwa SD Ar Rahman telah menerapkan nilai gotong royong kepada siswa.

\section{Faktor Pendukung dan Faktor Penghambat Implementasi Pendidikan Karakter di SD}

\section{Ar Rahman Kertosono}

Dalam pelaksanaan implementasi pendidikan karakter melalui budaya religius dalam mengembangkan soft skill di SD Ar Rahman Kertosono tentu terdapat faktor pendukung dan faktor penghambatt yang dihadapi dalam mencapai tujuan.

1. Faktor Pendukung Implementasi Pendidikan Karakter

\footnotetext{
${ }^{26}$ Mariatul Qibtiyah, wawancara, Kertosono, 28 Mei 2019

${ }^{27}$ Muclas Samani, Hariyanto, Pendidikan Karakter. (Bandung: PT Remaja Rosdakarya, 2013), 51.

${ }^{28}$ Observasi, SD Ar Rahman, 9 Mei 2019
} 
Implementasi pendidikana karakter melalui Budaya Religius dalam mengembangkan soft skill siswa membawa perubahan perilaku bagi siswa. Perilaku positif yang dibudayakan di sekolah akan menjadi kebiasaan yang positif bagi siswa saat di rumah maupun di lingkungan sosialnya. Ada beberapa faktor pendukung implementasi pendidikan karakter melalui Budaya Religius dalam mengembangkan soft skill siswa di SD Ar Rahman antara lain:

a. Sekolah

Sekolah memiliki peranan yang sangat penting dalam membentuk karakter siswa. Salah satu upaya yang dilakukan sekolah dalam membentuk karakter siswa adalah melalui budaya religius yang terwujud dalam pembiasaanpembiasaan. Pada setiap enam bulan sekali SD Ar Rahman menyelenggarakan seminar parenting bagi orang tua siswa yang narasumbernya merupakan seorang yang ahli dalam bidangnya. Dalam membentuk karakter siswa, sekolah memiliki buku performansi dimana buku tersebut berfungsi sebagai buku penghubung antara sekolah dengan orang tua. Dengan buku performansi tersebut guru dan orang tua akan lebih mudah memantau kegiatan siswa saat berada di sekolah maupun di rumah. Selain itu sekolah juga menyediakan grup WhatssApp untuk memudahkan orang tua dan guru dalam berkomunikasi mengenai perkembangan siswa.

Dalam pelaksanaan implementasi pendidikan karakter di SD Ar Rahman para guru bekerja secara team. Salah satu upaya yang dilakukan adalah guru menjadi suri tauladan bagi siswa. Guru juga memiliki buku penilaian kerja dan buku hafalan. Dengan begitu guru bukan hanya memberikan pengetahuan dan perintah saja namun juga menjadi suri tauladan bagi siswa.

b. Orang tua

Orang tua memiliki peranan yang sangat penting dalam mengembangkan karakter siswa karena pada hakikatnya orang tua dan keluarga merupakan madrasah pertama bagi siswa. Salah satu faktor pendukung orang tua dalam membentuk karakter siswa yaitu dengan mengikuti kegiatan parenting yang diselenggarakan oleh sekolah. Dengan kegiatan parenting tersebut diharapkan orang tua dan sekolah saling bekerjasama dalam mendidik siswa. Dengan orang tua mengisi buku performansi siswa maka sekolah akan lebih mudah memantau kegiatan-kegiatan yang dilakukan siswa saat berada di rumah. ${ }^{29}$ Orang tua siswa SD Ar Rahman senantiasa mendukung

${ }^{29}$ Nur Atiningsih, wawancara, Kertosono, 28 Mei 2019 
putra-putrinya mengikuti kegiatan yang diselenggarakan oleh sekolah seperti kegiatan utbond and outdoor education, kunjungan profesi dan kegiatan-kegiatan lainnya. ${ }^{30}$

c. Siswa

Salah satu faktor pendukung implementasi pendidikan karakter melalui Budaya Religius dalam mengembangkan soft skill siswa di SD Ar Rahman yaitu banyaknya perubahan pada diri siswa seperti yang diungkapkan oleh Nabila siswa kelas III SD Ar Rahman menyatakan bahwa setiap hari ia membaca Al-Qur'an saat berada di rumah karena terbiasa mengaji saat berada di sekolah. ${ }^{31}$ Ibu Mariatul Qibtiyah juga menyatakan bahwa para alumni SD Ar Rahman yang melanjutkan pendidikannya di Sekolah Menengah Pertama (SMP) dan sederajat senantiasa menyempatkan melakukan sholat dhuha saat jam istirahat. Hal ini menunjukkkan bahwa budaya-budaya yang ditanamkan pada siswa sejak dini maka akan menjadi kebiasaan bagi siswa saat berada di rumah, di sekolah maupun di lingkungannya. ${ }^{32}$

2. Faktor Penghambat Implementasi Pendidikan Karakter

Implementasi pendidikan karakter melalui Budaya Religius dalam mengembangkan soft skil siswa di SD Ar Rahman memiliki hambatan. Ada beberapa faktor yang menjadi penghambat dalam menerapkan pendidikan karakter di SD Ar Rahman antara lain:

a. Orang tua

Membentuk karakter seseorang bukanlah suatu hal yang mudah. Ada beberapa faktor yang menjadi kendala bagi sekolah dalam menerapkan pendidikan karakter antara lain ada beberapa orang tua siswa yang pasrah bongkokan dalam artian menyerahkan seluruh pendidikan anaknya kepada sekolah. ${ }^{33}$ Ibu Siti Farida Ariani menyatakan bahwa ada beberapa orang tua tidak mengikuti seminar parenting yang diselenggarakan oleh sekolah karena sibuk dengan pekerjaanya. Apa yang diterapkan di sekolah kurang mendapatkan dukungan dari orang tua dalam artian kurangnya teladan dari orang tua. Buku penghubung juga jarang diisi, hal ini menyebabkan sekolah merasa kesulitan dalam memantau perkembangan dan kegiatan siswa saat berada di rumah. ${ }^{34}$ Dari beberapa faktor tersebut sekolah terkadang merasa kesulitan dalam membentuk karakter siswa karena saat di sekolah siswa dibiasakan dengan

\footnotetext{
${ }^{30}$ Mariatul Qibtiyah, wawancara, Kertosono, 28 Mei 2019

${ }^{31}$ Nabila, wawancara, Kertosono, 9 Mei 2019

${ }^{32}$ Mariatul Qibtiyah, wawancara, Kertosono, 28 Mei 2019

${ }^{33}$ Nur Atiningsih, wawancara, Kertosono, 28 Mei 2019

${ }^{34}$ Siti Farida Ariani, wawancara, Kertosono, 28 Mei 2019
} 
kegiatan positif namun saat berada di rumah siswa menjadi tidak terkendali atau bebas dari pengawasan. Hal ini menjadi hambatan dalam menerapkan pendidikan karakter pada siswa. ${ }^{35}$

b. Siswa

Ibu Nur Atiningsih mengungkapkan bahwa faktor penghambat yang berasal dari diri siswa yaitu perbedaan karakter maupun sikap dan latar belakang siswa. Pada hakikatnya membentuk karakter seseorang bukanlah suatu hal yang mudah. Membentuk karakter seseorang membutuhkan waktu yang lama. Selain itu ada beberapa siswa yang terkadang tidak mematuhi peraturan sekolah. Hal ini menjadi hambatan terlaksananya implementasi pendidikan karakter melalui Budaya Religius dalam mengembangkan soft skill siswa di SD Ar Rahman. ${ }^{36}$

c. Tantangan dari luar

Tantangan dari luar yang menjadi hambatan implementasi pendidikan karakter melalui Budaya Religius dalam mengembangkan soft skill siswa antara lain pesatnya perkembangan teknologi dan informasi baik melalui media cetak, televisi, gadget maupun game online ikut andil dalam pembentukan karakter siswa, pengaruh globalisasi mengakibatkan semakin leluasa masuknya budaya luar dan mengesampingkan budaya lokal yang ada. ${ }^{37}$ Dalam pelaksanaan implementasi pendidikan karakter melalui Budaya Religius dalam mengembangkan soft skill di SD Ar Rahman Kertosono tentu terdapat faktor pendukung dan faktor penghambatt yang dihadapi dalam mencapai tujuan.

\section{Kesimpulan}

Dari pembahasan tentang implementasi pendidikan karakter melalui budaya religius dalam mengembangkan soft skill siswa di SD Ar Rahman Kertosono diatas, peneliti dapat menyimpulkan sebagai berikut:

1. Implementasi pendidikan karakter melalui budaya religius dalam mengembangkan soft skill siswa di SD Ar Rahman dilakukan melalui beberapa cara, diantaranya ialah:

a. Implementasi pendidikan karakter di SD Ar Rahman Kertosono dibudayakan dan disisipkan dalam semua mata pelajaran dan diaplikasikan dalam setiap kegiatan di sekolah. Baik di dalam maupun di luar kelas.

\footnotetext{
${ }^{35}$ Mariatul Qibtiyah, wawancara, Kertosono, 28 Mei 2019

${ }^{36}$ Nur Atiningsih, wawancara, Kertosono, 28 Mei 2019

${ }^{37}$ Mariatul Qibtiyah, wawancara, Kertosono, 28 Mei 2019
} 
b. Implementasi pendidikan karakter melalui budaya religius dalam mengembangkan soft skill siswa di SD Ar Rahman Kertosono adalah melalui pembiasaan, melaksanakan kegiatan pengembangan melalui budaya religius seperti kegiatan rutin, kegiatan spontan dan kegiatan teladan, menerapkan nilai-nilai karakter seperti nilai religius, peduli sosial, disiplin, mandiri, jujur, kreatif, sehat dan bersih, tanggung jawab serta gotong royong.

c. Dalam memantau kegiatan siswa saat berada di rumah maupun di sekolah, SD Ar Rahman Kertosono menggunakan buku perfomansi atau buku penghubung.

d. SD Ar Rahman Kertosono mimiliki rapot khusus yang berisi penilaian kegiatan non akademik siswa.

e. SD Ar Rahman Kertosono memiliki program pembelajaran khas yaitu program utama, program unggulan dan program penunjang.

2. Faktor Pendukung dan Faktor Penghambat serta Solusi Implementasi Pendidikan Karakter Melalui Budaya religius dalam Mengembangkan soft skill Siswa di SD Ar Rahman Kertosono

a. Faktor Pendukung Implementasi Pendidikan Karakter Melalui Budaya religius dalam Mengembangkan soft skill Siswa di SD Ar Rahman Kertosono

1) Keikutsertaan orang tua dalam seminar parenting menjadikan hubungan antara sekolah dan orang tua akan tercipta dengan baik dalam mencapai tujuan yang mulia yaitu terwujudnya pribadi yang berkarakter kuat.

2) Dengan mengisi buku perfomansi siswa, maka guru dan orang tua akan mengetahui sejauh mana perkembangan siswa saat berada di sekolah dan di rumah.

3) Orang tua senantiasa mendukung kegiatan-kegiatan yang ada di sekolah.

b. Faktor penghambat Implementasi Pendidikan Karakter Melalui

Budaya Religius dalam Mengembangkan soft skill Siswa di SD Ar Rahman Kertosono

1) Orang tua menyerahkan seluruh pendidikan anak kepada sekolah

2) Orang tua tidak mengikuti seminar parenting

3) Orang tua tidak mengisi buku perfomansi siswa

4) Pendidikan yang diterapkan di sekolah tidak diterapkan di rumah karena orang tua yang acuh.

5) Perbedaan karakter dan latar belakang siswa

6) Pesatnya teknologi informasi dan komunikasi seperti game online, televisi dan lain sebagainya yang berdampak buruk pada kehidupan siswa. 


\section{DAFTAR PUSTAKA}

Baedowi, Ahmad, Dkk. 2015. Manajemen Sekolah Efektif. Jakarta: PT Pustaka Alvabet.

Bafirman. 2016. Pembentukan Karakter Siswa. Jakarta: Rencana.

Hamid, Abdullah. 2017. Pendidikan Karakter Berbasis Pesantren. Surabaya: Imtiyaz.

Kementerian Pendidikan Nasional Badan Penelitian dan Pengembangan Pusat Kurikulum dan

Perbukuan. 2011. Pedoman Pelaksanaan Pendidikan Karakter. Jakarta: Departemen Pendidikan Dan Kebudayaan.

Kementerian Pendidikan Nasional Badan Penelitian dan Pengembangan Pusat Kurikulum dan

Perbukuan. 2010. Pengembangan Pendidikan Budaya Dan Karakter Bangsa. Jakarta:

Departemen Pendidikan dan Kebudayaan.

Kumalasari, Dyah. 2018. Agama Dan Budaya Sebgai Basis Pendidikan Karakter Di Sekolah. Yogyakarta: Suluh Media.

Lembaga Pendidikan Islam Dan Sosial Ar Rahman Kertosono. Diakses Pada April 1, 2019, Dari Http://lpiarrahman.sch.id/sd-kertosono

Moleong, Lexy, J. 2016. Metodelogi Penelitian Kualitatif . Bandung: PT Ramaja Rosdakarya. Safrudin. 2018. Pengembangan Kepribadian Dan Profesionalisme Bidan. Malang: Wineka Media.

Samani, Muclas, Hariyanto. 2013. Pendidikan Karakter. Bandung: PT Remaja Rosdakarya.

Siyoto, Sandu, M Ali Sodik. 2015. Dasar Metodelogi Penelitian. Yogyakarta. Literasi Media Publishing.

Sugiono. 2011. Metode Penelitian Kuantitatif, Kualitatif dan R\&D. Bandung: Alfabeta.

Sutardi. 2012. Solusi Mahir Kimia. Yogyakarta: Deeplubish CV Budi Utama.

Tim Penyusun Pusat Bahasa. Kamus Besar Bahasa Indonesia. Jakarta: Balai Pustaka.

Tune, Sumar Warni, Intan Abdul Rozak. 2016. Strategi Pembelajaran Dalam Implementasi Kurikulum Berbasis Soft Skill. Yogyakarta: Deeplubish.

Undang-Undang Republik Indonesia. 2007. Jakarta: Transmedia Pustaka. 92

Rianawati. 2014. Implementasi Nilai-Nilai Karakter Pada Mata Pelajaran PAI.

Pontianak: IAIN Pontianak.

Rosdiatun. 2018. Model Implementasi Pendidikan Karakte. Gresik: Caremedia Communacation. 